Popular Music (2020) Volume 39/3-4. (C) The Author(s), 2021. Published by Cambridge University Press, pp. 750-750 $10.1017 / \mathrm{S} 0261143021000015$

\title{
ERRATUM
}

Is it Still Good to Ya? Fifty Years of Rock Criticism 1967-2002. By Robert Christgau. Durham, NC: Duke University Press, 2018. 444 pp. ISBN 978-1-47800022-8.

Book Reports: a Music Critic on his First Love, which was Reading. By Robert Christgau. Durham, NC: Duke University Press, 2019. 398 pp. ISBN 978-1-47800030-3 - ERRATUM

\section{DAI GRIFFITHS}

doi: 10.1017/S0261143020000343, published by Cambridge University Press, 27 August 2020

The original published version of this article included an error in the second book title. A notice detailing this has been published and the error rectified in the online PDF and HTML copies.

\section{References}

Griffiths, D. (2020). Is it Still Good to Ya? Fifty Years of Rock Criticism 1967-2002. By Robert Christgau. Durham, NC: Duke University Press, 2018. 444 pp. ISBN 978-1-4780-0022-8.

Book Reports: A Music Critic on his First Love, which was Reading. By Robert Christgau. Durham, NC: Duke University Press, 2019. 398 pp. ISBN 978-1-4780-0030-3. Popular Music, 39(2), 384-389. 